\title{
Approaching Shared Heroes: Cultural Transfer and Transnational Jewish History
}

\author{
MICHA J. PERRY \\ University of Haifa, Haifa, Israel \\ E-mail: mperry2@univ.haifa.ac.il

\section{REBEKKA VOß} \\ Goethe-Universität, Frankfurt am Main, Germany \\ E-mail:voss@em.uni-frankfurt.de
}

\begin{abstract}
This special issue of Jewish History is devoted to shared heroes in Judaism, Christianity, and Islam. It explores diverse images of heroes that are shared by at least two of these religious traditions by comparing each figure's origin, inventions, and reinventions within varying cultural contexts in antiquity, the Middle Ages, and the early modern period and by highlighting the cross-cultural significance of their counterstories and entangled histories. The construction and deconstruction, interpretation and reception of these heroic figures and their sociocultural roles over time and space bear witness to the encounters of Jews and Judaism with neighboring cultures. The approaches to our subject presented in this collection illuminate how the long-established rubric of "the hero" benefits from a cross-cultural approach. In turn, empirical data culled from the cross-cultural study of heroes demonstrate the inner workings of cultural transfer and, we believe, contribute an original perspective to the field of transnational history, which focuses on cultural entanglement.
\end{abstract}

Keywords Heroes · Transnational history $\cdot$ Jewish historiography $\cdot$ Cultural transfer

\section{Heroic Entanglement}

A hero might be defined as a person who is admired for his great acts or exalted qualities. Classic Jewish heroes encompass biblical, rabbinic, and midrashic figures, including David, Esther, and Yohanan b. Zakkai, famous historical personages such as Simon Bar Kokhba, Moses Mendelssohn, and Yosef Trumpeldor, and heroic archetypes such as the martyr and the tzaddik. For decades, these heroes have been studied as windows on Judaism's central themes-especially during the biblical, rabbinic, and modern periods. Until recently scholarship has tended to concentrate on a singular moment or individual in Jewish history, or on a specific Jewish text (or group of texts), with little, if any, attention to cross-cultural considerations. Admittedly, folklorists have identified internationally transmitted themes and personae, ${ }^{1}$ and

\footnotetext{
${ }^{1}$ See the anthology Folktales of the Jews, ed. Dan Ben-Amos, 3 vols. (Philadelphia, 2006-11). See also, among others, Eli Yassif, "Intertextuality in Folklore: Pagan Themes in Jewish Folktales from the Early Modern Era," European Journal of Jewish Studies 3, no. 1 (2009): 57-80.
} 
scholars of comparative literature have contextualized biblical heroes within a broader literary universe. ${ }^{2}$ However, the study of shared heroes - characters who appear in changing garb across socioreligious groups-is still a lacuna. ${ }^{3}$

The heroes examined in this issue are either shared harmoniously, appearing in parallel stories, or presented in divergent portrayals, as when heroes are transformed into villains or counterheroes. ${ }^{4}$ Jews and Christians concurred on the whereabouts of the Ten Lost Tribes of Israel and the location of Prester John's kingdom, although they disputed their characteristics and their foretold roles. ${ }^{5}$ Whereas Muslims embraced Moses and Jesus in the succession of prophets that preceded Mohammad, premodern Christians condemned the "true prophet of Islam" as an emissary of the devil. ${ }^{6}$ Christianity also equated

${ }^{2}$ See, e.g., Michael E. Stone and Theodore A. Bergren, eds., Biblical Figures outside the Bible (Harrisburg, PA, 1998); Klaus-Peter Adam, "Saul as a Tragic Hero: Greek Drama and Its Influence on Hebrew Scripture in 1 Samuel 14,24-46 (10,8; 13,7-13a; 10,17-27)," in For and Against David: Story and History in the Books of Samuel, ed. A. Graeme Auld and Erik Eynikel (Leuven, 2010), 123-83; Royce M. Victor, "Delilah-A Forgotten Hero (Judges 16:4-21): A Cross-Cultural Narrative Reading," in Joshua and Judges, ed. Athalya Brenner and Gale A. Yee (Minneapolis, 2013), 235-55.

${ }^{3}$ Notable exceptions include Eva Haverkamp, "Martyrs in Rivalry: The 1096 Jewish Martyrs and the Thebean Legion," Jewish History 23, no. 4 (2009): 319-42; Elisheva Baumgarten and Rella Kushelevsky, "From 'The Mother and Her Sons' to 'The Mother of the Sons' in Medieval Ashkenaz" [in Hebrew], Zion 71, no. 3 (2006): 301-42; Richard A. Freund, "Alexander Macedon and Antoninus: Two Greco-Roman Heroes of the Rabbis," in Crisis and Reaction: The Hero in Jewish History, ed. Menachem Mor (Omaha, NE, 1995), 19-72; John Macdonald, "Joseph in the Qur' an and Muslim Commentary: A Comparative Study," pts. 1 and 2, The Muslim World 46, no. 2 (1956): 113-31; 46, no. 3 (1956): 207-24; Alessandro Grazi, "A Jewish Construction of a Catholic Hero: David Levi's 'A Pio IX," Studies in Christian-Jewish Relations 6 (2011): 1-15. In addition, several articles in Stone and Bergren, Biblical Figures, analyze the adaptations of biblical heroes in early Christian and Islamic traditions. See also the research agenda put forward in David B. Ruderman, "Three Contemporary Perceptions of a Polish Wunderkind of the Seventeenth Century," AJS Review 4 (1979): 143-63.

${ }^{4}$ We derive the term "counterhero" from the concept of counterhistory as developed by Amos Funkenstein and David Biale; see Amos Funkenstein, "History, Counterhistory, and Narrative," in Perceptions of Jewish History (Berkeley, 1993), 22-49; David Biale, "Counter-History and Jewish Polemics against Christianity: The Sefer toldot yeshu and the Sefer zerubavel," Jewish Social Studies 6, no. 1 (1999): 130-45. See below for a discussion of this notion in relation to the study of heroes.

${ }^{5}$ On Prester John, see Micha Perry, "The Imaginary War between Prester John and Eldad the Danite and Its Real Implications," Viator: Medieval and Renaissance Studies 41, no. 1 (2010): 1-23. For a recent study of the Red Jews, a Germanic variant on the Ten Lost Tribes in Jewish and Christian lore, see Rebekka Voß, "Entangled Stories: The Red Jews in Premodern Yiddish and German Apocalyptic Lore," AJS Review 36, no. 1 (2012): 1-41. These studies employ a cross-cultural and transnational approach similar to the one advanced here.

${ }^{6}$ Minou Reeves, Muhammad in Europe: A Thousand Years of Western Myth-Making (New York, 2003). 
the Jewish Messiah with the Antichrist. ${ }^{7}$ Not coincidentally, the Christian biography of the Antichrist bears strong commonalities with Toledot Yeshu, a Hebrew account of the life of Jesus written from an anti-Christian perspective. $^{8}$

The cultural transformations of the concepts of "the hero" and "heroism" that are explored in this volume in relation to various personalities demonstrate that Jews, Christians, and Muslims were aware of and responded to others' renderings of their own heroes. The common and contrasting roles that select heroes have filled for these groups reveal how different societies, cultures, and religions have interacted-whether consciously or unconsciously, synchronically or diachronically. In recognizing the unique vantage point that this perspective offers to studies of cultural encounter and exchange in the Jewish experience, this issue of Jewish History aims to contextualize the Jewish hero and offer its manifestations as a paradigm for cultural transfer. ${ }^{9}$

\section{Cultural Transfer and Transnational Studies}

Over the last two decades, historians have begun to pay closer attention to comparative analysis, cultural encounter, and cultural transfer. The methodological developments associated with these efforts in various historical fields converge with the emerging focus on transnational history, a significant shift favoring more nuanced attitudes toward the relations between societies and cultures. ${ }^{10}$ Transnational methodologies move beyond nation-states

\footnotetext{
${ }^{7}$ Andrew C. Gow, "The Jewish Antichrist in Medieval and Early Modern Germany," in $\mathrm{Me}$ dieval Encounters 2, no. 3 (1996): 249-85; Jeremy Cohen, "Be-'ekvot ha-Anti-Kristos vekesharav ha-yehudiyim," in Rishonim ve-aharonim: Mehkarim be-toldot Yisra'el mugashim leAvraham Grossman, ed. Joseph R. Hacker, Yosef Kaplan, and Benjamin Z. Kedar (Jerusalem, 2010), 29-45.

${ }^{8}$ For the most recent research on Toledot Yeshu, see Peter Schäfer, Michael Meerson and Yaacov Deutsch, eds., Toledot Yeshu ("The Life Story of Jesus") Revisited: A Princeton Conference (Tübingen, 2011).

${ }^{9}$ The doctoral students' conference "Heroes across Borders" held at the University of Mannheim in September 2013 employed a similar transnational approach by focusing on the adaptation and interpretation of hero myths across spatial, chronological, and cultural borders. See Gero Schreier and Jakob Willis, "Tagungsbericht 'Helden über Grenzen?': Transnationale(s) Mythen und Heldentum von der Antike bis zur Moderne," Helden, heroes, héros 1, no. 1 (2013): 95-97.

${ }^{10}$ The shift toward transnational history was catalyzed during the mid-1990s by criticisms of the comparative approach to historiography. On this field in general, see Klaus Kiran Patel, "Transnational History," European History Online (EGO), December 3, 2010, http://ieg-ego.eu/en/threads/theories-and-methods/transnational-history/klaus-kiran -patel-transnational-history; C. A. Bayley et al., "AHR Conversation: On Transnational
} 
as closed units and attempt to weave seemingly disparate narratives into a larger fabric that more accurately incorporates the complexity of cultural interactions. More broadly, the transnational approach stresses connections between peoples and cultures that transcend not only politically bounded territories such as principalities, states, and empires but also cultural and social entities. Whereas the method of historical comparison explores similarities and differences between independent units, the transnational approach prioritizes the multidirectionality of cultural relationships. ${ }^{11}$

The adjectives that characterize transnational history-shared or entangled, ${ }^{12}$ connected, ${ }^{13}$ braided, ${ }^{14}$ and crossed ${ }^{15}$ - reflect a concern with interconnections on synchronic and diachronic levels rather than with static circumstances. Thus, instead of an examination of "influence," we find a literature that strives to capture dynamic and mutually informing positions. This does not imply that transnationalism negates differences; rather, it seeks to uncover commonalities that effectively bind, connect, and build social and cultural units. In other words, a transnational stance challenges any notion of fixed entities by stressing the unique traits that shape culture and placing them in the context of broader sociocultural tendencies. Thus continuity and change are examined within a common frame. ${ }^{16}$

History," American Historical Review 111, no. 5 (2006): 1440-64. For a concise overview of the methodological debate, see Hartmut Kaelble, "Between Comparison and Transfers-and What Now? A French-German Debate," in Comparative and Transnational History: Central European Perspectives and New Approaches, ed. Heinz-Gerhard Haupt and Jürgen Kocka (New York, 2009), 33-39.

${ }^{11}$ Cf. the definitional distinction in Jürgen Kocka and Heinz-Gerhard Haupt, "Comparison and Beyond: Traditions, Scope, and Perspectives of Comparative History," in Haupt and Kocka, Comparative and Transnational History, 1-30.

${ }^{12}$ The concept of "shared" or "entangled history" developed by Shalini Randeria and Sebastian Conrad highlights the cultural interdependence of colonized peoples and colonizing societies, with transfers flowing in both directions. Sebastian Conrad and Shalini Randeria, eds., Jenseits des Eurozentrismus: Postkoloniale Perspektiven in den Geschichts- und Kulturwissenschaften (Frankfurt, 2002).

13 "Connected history" is associated with Sanjay Subrahmanyam, who studies cultural entanglement among geographically distant peoples by exploring political, commercial, and cultural links between early modern Europe and South Asia. Sanjay Subrahmanyam, "Connected Histories: Notes towards a Reconfiguration of Early Modern Eurasia," Modern Asian Studies 31, no. 3 (1997): 735-62, and Explorations in Connected History, 2 vols. (New York, 2011-12). ${ }^{14}$ Natalie Zemon Davis is currently writing a book entitled Braided Histories, for example. ${ }^{15}$ The term histoire croisée adds a multilateral element to the transnational toolbox. See Michael Werner and Bénédicte Zimmermann, "Beyond Comparison: Histoire Croisée and the Challenge of Reflexivity," History and Theory 45 (February 2006): 30-50.

${ }^{16}$ See Subrahmanyam, "Connected Histories," 759. With regard to transnational and transcultural religions, i.e., Judaism, Christianity, and Islam, among others, Jan Assmann has argued for the religious canon as a form of cultural memory that became the principal element of 
The underlying premise of transnational history is that shared history (e.g., events, processes, traditions, ideas, institutions, networks, and material goods) might be experienced, interpreted, and recounted differently across cultures. Hence, during recent decades, the study of history has increasingly attended to "cultural transfer," "cultural exchange," and "cultural hybridity." recognized as subjects of inquiry: the changes to these goods that result from having been transferred among cultures are now deemed worthy of investigation, as is the role of each receiving community in this process. ${ }^{18}$ What becomes most visible in our study of shared heroes is that the very act of sharing a particular cultural object may influence how various cultures absorb it.

Jewish history offers a prime test case for writing transnational history. The qualities that have characterized the Jewish diaspora from antiquity through modernity - dispersion among cultures worldwide, different levels of migration, and maintaining extraterritorial in-group ties while being immersed (to varying degrees) in a host culture-are highly compatible with a transnational or global perspective. ${ }^{19}$ David Myers, for example, has presented Jewish history in the diaspora as an ideal theme for research on the mechanisms of cultural exchange, describing Jews as a "dynamic transnational group." 20 Myers is, in our view, justified in his statement that a shift away from the binary poles of outright rejection versus blanket adoption is a

identity in response to (cultural) globalization. Jan Assmann, "Globalization, Universalism, and the Erosion of Cultural Memory," in Memory in a Global Age: Discourses, Practices, and Trajectories, ed. Aleida Assmann and Sebastian Conrad (Basingstoke, 2010), 121-37.

${ }^{17}$ Michel Espagne, in particular, has developed the concept of transferts culturels; Michel Espagne, "Sur les limites du comparatisme en histoire culturelle," Genèses 17 (1994): 112-21, and "Au delà du comparatisme," in Les transferts culturels franco-allemands (Paris, 1999), 35-49. On cultural exchange and cultural hybridity, see Peter Burke, Kultureller Austausch (Frankfurt, 2000), and Cultural Hybridity (Cambridge, 2009).

${ }^{18}$ Peter Burke among others emphasizes active reception; see Peter Burke, "Cultures of Translation in Early Modern Europe," in Cultural Translation in Early Modern Europe, ed. Peter Burke and R. Po-Chia Hsia (Cambridge, 2007), 7-38. The concept of "influence" has been criticized as suggesting a one-way relationship between a strong and active partner and a weak and passive partner; see, e.g., Robert Bonfil, Jewish Life in Renaissance Italy (Berkeley, 1994), 145-46.

${ }^{19}$ See David Biale, introduction to Cultures of the Jews: A New History, ed. David Biale (New York, 2002). For general theories about diaspora within a transnational framework, see Rainer Bauböck and Thomas Faist, eds., Diaspora and Transnationalism: Concepts, Theories, and Methods (Amsterdam, 2010).

${ }^{20}$ David N. Myers, "Jenseits des Einflusses: Hin zu einer neuen Kulturgeschichte?" Aschkenas 18/19, no. 2 (2008/9): 502. 
defining element of both Jewish cultural history and transnational studies. ${ }^{21}$ This observation, also articulated by others who view the cultural and global turn in Jewish studies as parallel to general trends, implies that Jewish historians are already writing transnational history in principle, though often without explicit reference to its theoretical foundations. ${ }^{22}$

Just as Jewish history typically follows trends in the broader field of history, so too with research on cultural encounter. Even though Jews have hardly been studied within the framework of an explicitly transnational methodology, ${ }^{23}$ in the wake of the cultural turn, cross-cultural interactions and cultural transfer have come to be en vogue in Jewish studies. It is noteworthy that, whereas transnational studies first developed from discussions in modern history in which the nation-state was accepted as a normative organizing principle, ${ }^{24}$ contemporary scholars of medieval Judaism in particular have contributed a corrective to the earlier depictions of the culturally isolated Jew in the eternally segregated "ghetto" prior to emancipation. ${ }^{25}$ During the

\footnotetext{
${ }^{21}$ Myers observes that Jewish scholars-Simon Rawidowicz, Gerson Cohen, and Amos Funkenstein among them-anticipated major theories about cultural transfer between the colonizer and the colonized, such as those by Homi Bhabha, Stuart Hall and Edward Said. Ibid. ${ }^{22}$ Dan Diner, "Geschichte der Juden: Paradigma einer europäischen Geschichtsschreibung," in Gedächtniszeiten: Über jüdische und andere Geschichten (Munich, 2003), 246-62; Shulamit Volkov, "Jewish History: The Nationalism of Transnationalism," in Transnationale Geschichte: Themen, Tendenzen und Theorien, ed. Gunille Budde, Sebastian Conrad, and Oliver Janz (Göttingen, 2006), 190-210; Martina Steer, "Kultureller Austausch in der jüdischen Geschichte der Frühen Neuzeit," in Kultureller Austausch: Bilanz und Perspektiven der Frühneuzeitforschung, ed. Michael North (Cologne, 2009), 25-41; David Penslar, "The New Face of German-Jewish Historiography: Comparative, Trans-National, International," Leo Baeck Institute Yearbook 54 (2009): 10-14.

${ }^{23}$ A collection edited by Wolfgang Schmale and Martina Steer, Kulturtransfer in der jüdischen Geschichte (Frankfurt, 2006), represents an explicit effort to apply the concept of cultural transfer to Jewish studies. A special issue of Transversal 5 (2004) has invited studies that approach modern Jewish culture through the concept of hybridity. Moshe Rosman has examined theoretical issues in Jewish historiography in light of postmodernism; Moshe Rosman, How Jewish Is Jewish History? (Oxford, 2007). A recent collection of essays addresses this same issue from a range of directions: Jeremy Cohen and Moshe Rosman, eds., Rethinking European Jewish History (Oxford, 2009).

${ }^{24}$ In recent years, however, important contributions have established the global character of the medieval and early modern periods. See, e.g., Jerry H. Bentley, Old World Encounters: CrossCultural Contacts and Exchanges in Pre-Modern Times (New York, 1993); Robert Muchembled and William Monter, eds., Cultural Exchange in Early Modern Europe, 4 vols. (Cambridge, 2007); Michael Borgolte and Matthias M. Tischler, eds., Transkulturelle Verflechtung im mittelalterlichen Jahrtausend: Europa, Ostasien und Afrika (Darmstadt, 2012).

${ }^{25}$ The first two decades of this historiographic trend are discussed in David Berger, "A Generation of Scholarship on Jewish-Christian Interaction in the Medieval World," Tradition: A Journal of Orthodox Jewish Thought 38, no. 2 (2004): 4-14; Ivan G. Marcus, "Israeli Medieval
} 
last twenty years, this overall development in Jewish studies has been exemplified by the growing body of works on Jewish-Christian-Muslim relations in various eras and on quotidian interactions between Jews and their Christian or Muslim counterparts in many spheres, including commerce, religion, culture, and everyday life. ${ }^{26}$

This shift has had a tangible impact on the perception of Jews as active participants in history, an understanding that was inherent in the methodological changes of the mid-1990s and has become more explicit in the innovative works of the younger generation of historians. Works that explore cultural entanglement do not present Jews as merely influenced by events or cultural developments in the Christian or Muslim worlds; rather, they investigate Jews as historical actors in specific places through their engagement with the changing conditions of their lives. ${ }^{27}$

In addition to the much-studied cultural interactions between Jews and "Others," scholars are increasingly considering transfers among Jewish cultural units (e.g., between Sephardic and Ashkenazic societies). ${ }^{28}$ Here, transnational perspectives are consciously employed to reveal the artifice of national and other conventional spatial categories as key points of reference. ${ }^{29}$ For example, the approach articulated in David Ruderman's new

Jewish Historiography: From Nationalist Positivism to New Cultural and Social Histories," Jewish Studies Quarterly 17, no. 3 (2010): 244-85.

${ }^{26}$ Modern Jewish history, on the other hand, has increasingly ventured into the comparative realm since the mid-1990s. See, e.g., Rainer Lidtke, Jewish Welfare in Hamburg and Manchester, 1850-1914 (Oxford, 1998); Rainer Lidtke and David Rechter, eds., Two Nations: British and German Jews in Comparative Perspective (Tübingen, 1999); Michael Brenner, ed., Jewish Emancipation Reconsidered: The French and German Models (Tübingen, 2003); David Sorkin, Religious Enlightenment: Protestants, Jews, and Catholics from London to Vienna (Princeton, NJ, 2011).

${ }^{27}$ See, e.g., Debra Kaplan, Beyond Expulsion: Jews, Christians, and Reformation Strasbourg (Stanford, CA, 2011), 6; Maud Mandel, "Assimilation and Cultural Exchange in Modern Jewish History," in Cohen and Rosman, Rethinking European Jewish History, 74, 88; Moshe Rosman, "Jewish History across Borders," in Cohen and Rosman, Rethinking European Jewish History, 15-29.

${ }^{28}$ See, e.g., Abraham Grossman, "Relations between Spanish and Ashkenazi Jewry in the Middle Ages," in Moreshet Sefarad: The Sephardic Legacy [in Hebrew], ed. Haim Beinart (Jerusalem, 1992), 220-39; Israel M. Ta-Shma, "Toward a History of the Cultural Links between Byzantine and Ashkenazic Jewry," in Me'a She'arim: Studies in Medieval Jewish Spiritual Life in Memory of I. Twersky [in Hebrew], ed. Gerald Blidstein et al. (Jerusalem 2001), 61-71; Judah Galinsky, "Ashkenazim in Sefarad: The Rosh and the Tur on the Codification of Jewish Law," Jewish Law Annual 16 (2006): 3-23.

${ }^{29}$ At the Association for Jewish Studies conference in 2013, a roundtable discussion entitled "Jewish History and the "Transnational Turn" engaged the methodology and framework of transnational history as it pertains to modern Jewish history. See also, e.g., Ava F. Kahn and Adam Mendelsohn, eds., Transnational Traditions: New Perspectives on American Jewish History (Detroit, 2014). 
cultural history of early modern Jews highlights cultural conversations across geographical borders while acknowledging the contributions of Sanjay Subramanyam's "connected histories" and Jerry H. Bentley's groundbreaking approach to defining the early modern Jewish world according to binding commonalities. ${ }^{30}$ Moshe Rosman also appeals for a transnational (nonpolitical, regional) space in which to study and write Jewish history with an emphasis on cultural, social, or economic geography. ${ }^{31}$ These two scholars demonstrate how productive engagement with the transnational toolbox challenges existing paradigms in Jewish history. ${ }^{32}$

\section{The Transnationalism of Shared Heroes}

The articles presented here build on the current trend in Jewish historiography that views Jewish history as intrinsically transnational. By analyzing heroes through the lens of cultural entanglement, these authors challenge conventional assumptions about their subjects. Their comparisons of each Jewish hero's cultural, religious, and social functions to his roles in other religious cultures, contemporaneous and asynchronous, open new perspectives on the origins and development of that figure's heroism. These case studies thus contribute qualitatively to our knowledge of Jewish history. Moreover, this

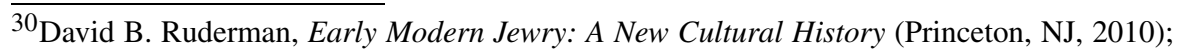
Subrahmanyam, "Connected Histories," 759; Jerry H. Bentley, "AHR Forum: Cross-Cultural Interaction and Periodization in World History," American Historical Review 101, no. 3 (1996): 749-70, and "Early Modern Europe and the Early Modern World," in Between the Middle Ages and Modernity: Individual and Community in the Early Modern World, ed. Charles H. Parker and Jerry H. Bentley (Lanham, MD, 2007), 13-31.

${ }^{31}$ Rosman, "Jewish History across Borders." In a similar attempt, Shlomo Berger has studied the Ashkenazi diaspora as a unified geographical region; Shlomo Berger, "Functioning within a Diasporic Third Space: The Case of Early Modern Yiddish," Jewish Studies Quarterly 15 (2008): 72. Jonathan Israel, among others, speaks of "trans-European and trans-Near Eastern" Sephardic networks; Jonathan I. Israel, Diasporas within a Diaspora: Jews, Crypto-Jews, and the World Maritime Empires (1540-1740) (Leiden, 2002), 93. See also Yosef Kaplan, An Alternative Path to Modernity: The Sephardi Diaspora in Western Europe (Leiden, 2000). Applied regional Jewish history is exemplified by Adam Teller's study of the Hasidic movement and its efforts to overcome the geographic barriers that divided eighteenth-century Eastern European Jewry; Adam Teller, "Hasidism and the Challenge of Geography: The Polish Background to the Spread of the Hasidic Movement," AJS Review 30, no. 1 (2006): 1-29.

${ }^{32}$ David Sorkin's forthcoming history of Jewish emancipation also benefits from a transnational approach. His preliminary studies include David Sorkin, "Beyond the East-West Divide: Rethinking the Narrative of the Jews' Political Status in Europe, 1600-1750," Jewish History 24 (2010): 248; and "Is American Jewry Exceptional?: Comparing Jewish Emancipation in Europe and America," American Jewish History 96 (2010): 175-200.
} 
series of articles provides data that may fruitfully be integrated into the theoretical framework of transnationalism and help to rectify the disjuncture between designating a group or process as "cross-cultural" and furnishing empirical data for the inner workings of cultural transfer, an issue that Francesca Trivellato recently raised. ${ }^{33}$

One clear advantage of bringing a transnational approach to the study of heroes stems from its emphasis on crossing cultural borders. Applied broadly and chronologically, transnational history enables us to examine Jewish heroes "at both the point of departure and that of arrival" 34 and the convergence of the paths between those points. We therefore become better equipped to follow a historical subject that is constantly changing and to tell a story of entanglement on numerous planes, combining not only time and space but also multiple cultural and historical perspectives, as the authors of this volume demonstrate. Through the prism of transnationalism, new insights may be gained on how religious traditions share the symbolic figures studied here or, to the contrary, how they assert competing claims to them. While various modes of sharing are represented, these articles, grouped chronologically, show that the very images of these figures as heroeswhether saintly or sinister, contested or not-were derived from their crosscultural significance.

The opening article by David Biale highlights how similar cultural usages of a heroic figure may have developed independently despite having been drawn from a common basis in the Hebrew Bible. It considers an unlikely biblical hero, Korah, the Levite who challenges Moses's leadership in Numbers 16 and is therefore regarded as an archvillain. This work examines how postbiblical Jewish, patristic, and Muslim sources reappropriated and transformed his image. For later Judaism, Christianity, and Islam, Korah was not a pure villain but a more ambiguous figure. Biale reveals how each of these three traditions creatively reworked the original text to fit their own political and religious contexts, casting Korah as a trickster hero, a rebellious rabbi, a sacrilegious bishop, or a wealthy sinner.

While Biale studies his hero from the perspective of a commonly applied literary model, the other four authors engage various reactions toward heroic constructions of the "Other," stressing the connections between each tradition's interpretations and their mutual borrowing and reworking of motifs. Eyal Ben-Eliyahu's article concentrates on the relationships between heroes

\footnotetext{
${ }^{33}$ Francesca Trivellato, The Familiarity of Strangers: The Sephardic Diaspora, Livorno, and Cross-Cultural Trade in the Early Modern Period (New Haven, CT, 2009), 1. Trivellato's monograph, an in-depth analysis of Jewish merchants as cross-cultural brokers, demonstrates how empirical data on this cohort illustrates theories of cultural encounters.

${ }^{34}$ See Patricia Seed on migration in Bayley, "AHR Conversation," 1443.
} 
and geography. It explores how a locale could cross cultures in a battle over a number of shared and exclusive heroes-God, the Shekhinah, Jesus, and the Messiah - and at the same time itself become a holy hero, tainted hero, and counterhero. This study shows how Christianity acquired and expanded Jewish traditions of the special bond between God and the Mount of Olives, thereby situating Jesus's ascension to Heaven and scenes of resurrecting the dead in that place. Under Christian rule, an enormous cross was erected on its peak, replacing the Shekhinah with a representation of Jesus in the contemporaneous mindset. Once it became dominated by Christian imagery, Jews distanced themselves from the mountain and their own associated traditions. However, this state of affairs lasted only until the Muslim conquest liberated the Mount of Olives from the image of Christ in Jewish minds. Ben-Eliyahu shows the fascinating ways in which the Muslim conquest reversed the balance between Judaism and Christianity: it allowed Jews not only to reaffirm their own heroic traditions but also to appropriate Christian traditions to create something new.

Lucia Raspe brings us to the High Middle Ages, specifically to a competition over the authenticity of a hero that was waged between Jews and Christians in the Rhineland. The tale of Rabbi Amram of Mainz, based on the legend of St. Emmeram of Regensburg, has long been considered a classic case of a Jewish narrative that was borrowed from Christian hagiography. Drawing on Christian and Jewish literary and archival sources, Raspe takes a fresh look at this material, showing that Jewish authors reappropriated writings about a Christian saint with great sophistication. Rather than simply wrapping a Christian hero in a Jewish plot, they implied that their own (clearly derivative) version transmitted religious truth, in contrast to the fraudulent account being circulated by the ostensibly more successful Christian cult. These Jews harnessed intimate knowledge of a Christian legend to counter the Church with its own weaponry.

Rachel Greenblatt studies Jewish and Christian saints within an early modern polemical framework. In late seventeenth-century Prague, when a Jewish youth named Simon Abeles left the Jewish quarter to study for conversion to Christianity, returned home without converting, and then died, the case became a cause célèbre: Simon was memorialized as an unofficial Christian saint in broadsides, pamphlets, and songs. A burning dispute erupted between Christians and Jews in Prague, with each population promoting saintlike heroes and countersaints for its youths to emulate. For Catholics, such activity was part of a religious renewal that had reached its apex after a decades-long process of purging Bohemia of Protestant influences. For Jews, it represented active resistance against Christian triumphalism.

In contrast, the concluding article by Rebekka Voß traces the entangled history of a heroic personage who was literally shared by early modern 
Jews and Christians: Charles V, king of Spain and emperor of the Holy Roman Empire. Voß's work illuminates how sixteenth-century Jews came to view this Catholic emperor as their hero. Contemporaneous Hebrew sources substantiate a shared sixteenth-century European culture that regarded this mighty Christian Emperor as a salvific figure for Jews and Christians alike due to his politics of crusade and church reform. Voß demonstrates the extent to which Jewish historiographic and prophetic writings embraced the widespread Christian tendencies to identify Charles V as the glorious universal monarch who would reign at the culmination of human history and integrated these notions into their own cultural system. But even if the Jewish heroization of Emperor Charles $\mathrm{V}$ required the embrace of imagery from a Christian source, its norms were only partially adopted and remained ideologically contested.

The articles collected in this issue situate their heroes and counterheroes, saints and countersaints in a complex web of cultural interdependencies, affirming Jews as active agents throughout history rather than mere cultural consumers. Furthermore, extending transnational perspectives to the topic of Jewish heroes underscores the need to track the origins of symbolic figures that were shared by more than one culture either to a common source, as in the case of Korah, or to their mirror image in another culture, as with Emmeram of Regensburg and Amram of Mainz or Jesus and the Jewish Messiah on the Mount of Olives. In the most dramatic cases, a Jewish youth who considered conversion but ultimately remained Jewish became a Christian martyr, and a Christian emperor who claimed a universal monarchy emerged as a Jewish quasi-messianic hero.

The theme of shared heroes presents a model of how Jews, Christians, and Muslims have constantly appropriated and reinterpreted one another's symbols and narrative devices to translate history for their own communities. Via shared heroes, each party reinforced its own agenda and confirmed its own traditions while seeking to challenge the other's ideology and self-concept. This is true not only for cases in which a heroic image is adopted and dressed in new garb, or in which one hero is substituted for another, albeit retaining some of the prior hero's features, or in which a new counterhero is introduced, but also in instances of mutually acclaimed heroism. The study of shared heroes thus benefits from Amos Funkenstein and David Biale's approach to counterhistory: each party deconstructs the adversary's collective narrative, negating the identity of the other by absorbing the other's motifs and ascribing new meanings to them. ${ }^{35}$ Effectively, the historiographic approach of counterhistory attests to the limits of shared heroism.

\footnotetext{
${ }^{35}$ Funkenstein, "History, Counterhistory, and Narrative," 36. For a similar application of counterhistory as a key to the Red Jews, see Voß, "Entangled Stories."
} 
The study of shared heroes in Judaism, Christianity, and Islam can thus serve as a tool for refining models of cultural contact on a spectrum from rivalry to convivencia. Jewish heroism, oscillating between cultural hybridity and conflict with a Christian and/or Muslim majority, allows us to address "sharing" and "competing" together. The evidence collected here demonstrates how cultures can construct boundaries while simultaneously participating in multicultural societies. ${ }^{36}$ Further, this collection makes clear that transnational historical study does not automatically compromise careful analysis of local contexts. It is true that writing global history entails the danger of neglecting spatial embeddedness in favor of connections and transfers. ${ }^{37}$ But the authors in this volume each integrate various local, regional, and global contexts, and their articles confirm that transnational history is simultaneously local and global. ${ }^{38}$

To date, the cultural turn in Jewish studies has hardly been acknowledged in related disciplines. ${ }^{39}$ As a transnational reality, however, cultural transfer from a Jewish vantage point has significant insights to contribute to the methodologies of transnational history. The studies of shared heroes collected here indicate that Jewish history can help transnationalism overcome two inherent polarizations: the false dichotomies of "sharing" versus "competing" and of local versus global.

Acknowledgments The articles in this issue of Jewish History were first presented at the conference "Counter-Stories and Entangled Histories: Shared Heroes in Judaism, Christianity, and Islam," Columbia University, New York, November 15-16, 2010. Our heartfelt thanks go to the Columbia University Institute for Israel and Jewish Studies, the program in Judaic Studies at Yale University, and the Columbia University Institute for Religion, Culture, and Public

\footnotetext{
${ }^{36}$ Jewish history provides a range of models for contact between cultures that live in close proximity, a feature that has been overlooked in most studies of cultural transfer; cf. Martina Steer, "Einleitung: Jüdische Geschichte und Kulturtransfer," in Schmale and Steer, Kulturtransfer, 16.

${ }^{37}$ See, e.g., Sarah Hagmann and Melinda Sudibyo, "Narrating an Entangled World: To What End(s) Do We Write Global History?," H-Soz-Kult, October 8, 2014, http://www.hsozkult.de /hfn/conferencereport/id/tagungsberichte-5591; Angelika Epple, "Lokalität und die Dimensionen des Globalen: Eine Frage der Relationen," in "Lokalität und transnationale Verflechtungen," ed. Felix Brahm, Angelika Epple, and Rebekka Habermas, special issue, Historische Anthropologie 21, no. 1 (2013): 4-25.

${ }^{38} \mathrm{Cf}$. Angelika Epple's important theoretical approach to global microhistory in Angelika Epple, "Globale Mikrogeschichte: Auf dem Weg zu einer Geschichte der Relationen," in Im Kleinen das Große suchen: Mikrogeschichte in Theorie und Praxis, ed. Ewald Hiebl and Ernst Langthaler (Innsbruck, 2012), 37-47, and “'Global History' and 'Area History': Plädoyer für eine weltgeschichtliche Perspektivierung des Lokalen," in Area Studies und die Welt: Weltregionen und neue Globalisierung, ed. Birgit Schäbler (Vienna, 2007), 90-116.

${ }^{39}$ Steer, "Einleitung," also comments on this lack of acknowledgment.
} 
Life for their generous sponsorship of this conference, and we extend special appreciation to Jeremy Dauber for hosting this event at Columbia University. We are grateful to Kenneth Stow, founding editor of Jewish History, for proposing the publication of this special issue and to the journal's past and current editors, Jay Berkovitz, Francesca Trivellato, and Ephraim Kanarfogel, for their energetic support. This project could not have reached fruition without the stimulating discussions that took place during our conference in New York: our gratitude goes to every participant for bringing his or her research and questions to that forum. Finally, we are deeply thankful to David Ruderman and David Biale for their careful reading of an early version of this introductory essay, and we thank this journal's anonymous reviewers for further suggestions toward its improvement. 